\title{
ANALYZING AUDIENCE AWARENESS IN ACADEMIC WRITING AMONG UNDERGRADUATES
}

\author{
Noor Hanim Rahmat \\ Universiti Teknologi Mara, Selangor Darul Ehsan, Malaysia \\ E-mail: patanim@gmail.com
}

\begin{abstract}
The teaching of writing has undergone many stages over the years-from product approach, to process approach, and then to cognitive approach. Recently, the approaches to the teaching of writing have shifted to social orientation. Researchers are encouraged to write for specific audiences. We undergo through three basic writing stages: (a) planning, (b) translating and (c)evaluating. Generally all writers will undergo these three processes, but what differentiates one writer form the other is the way they behave in each process. Nevertheless, better writers write with the audience in mind and are more careful with their writing process. As such, audience awareness is a characteristic of skilled writers and some writers write with the audience, while some do not. This study explores the writing process and audience awareness of undergraduates who have undergone a semester of a course in research writing. Using a questionnaire as the instrument, the quantitative data reveal interesting implications towards the teaching of academic writing in higher institutions.
\end{abstract}

Keywords: writers, writing process, audience awareness, research writing, undergraduates

\begin{abstract}
Abstrak
Pengajaran penulisan telah melalui banyak tahap selama beberapa tahun ini. Ia bermula dengan cara pengajaran secara produk, kemudian cara proses dan selepas itu secara kognitif. Kebelakangan ini, pengajaran penulisan telah berpaksikan orientasi sosial. Penulis disaran agar menulis dengan memikirkan pembaca yang berlainan. Lazimnya, penulis akan melalui tiga peringkat yang asas iaitu (a) perancangan, (b) penterjemahan, dan (c) penilaian. Secaranya, semua penulis akan melalui ketiga-tiga proses ini, yang berbeza Cuma cara setiap apa yang setiap penulis buat dalam setiap peringkat. Walau bagaimanapun, penulis yang lebih baik akan menulis dengan mengambil apa pembaca fikir dan akan lebih berhati-hati dalam proses penulisan. Kesedaran pembaca merupakan satu karekistik penulis yang mahir.Kajian ini mengkaji proses penulisan dan kesedaran pembaca di kalangan pelajar universiti. Pelajarpelajar dalam kajian ini telah melalui satu semester kursus dalam penilisan kajian. Kajian ini menggunakan sola selidik sebagai instrument. Data kuantitatif ini akan menunjukkan penemuan yang menarik dalam pengajaran penulisan akademik di peringkat pengajian tinggi.
\end{abstract}

Kata kunci: penulis, proses penulisan, kesedaran pembaca, penulisan kajian, pelajar university

\section{INTRODUCTION}

Research writing in universities is not a "favourite" subject among undergraduates in higher institutions of learning. The course requires students to spend long hours of planned time doing something they find most challenging. According to Flower and
Hayes (1981), researchers go through three basic writing stages and they are (a) planning, (b) translating and (c) evaluating. Generally all researchers will undergo these three processes, what differentiates one writer form the other is the way they behave in each process. The research by Kara (2013) 
suggested that when writing research, nonexperienced researcher lack strategies like (a) organizing ideas, (b) gathering information and (c) combining ideas. In addition to that, Hanizah and Moore (2003) audience awareness is a characteristic of experienced researcher. More experienced researcher write with the audience in mind and are more careful with their writing process.

Writing is not a passive activity. The writer writes for a particular audience. Many activities actually take place while the writer is writing. The writing does not end when the writer finished writing the essay. Another set of activities will then take place. Writing then can be seen from three different perspectives. Writer writes for a particular purpose. The content, context and style of the writing differ for different purposes. As such, the writer is alone in the writing process. He or she has to think of who the writing is intended for. In addition to that, what is written, how it is written, and who the writer is, is actually shaped by his or her background knowledge as well as his or her social interaction he or she is involved in. So, from this social perspective, writing well is not merely having the ability to write in the proper form (grammar and vocabulary), but also writing in the proper genre for the particular task.

On the other hand, the cultural aspect of writing has been the subject of debates in the area of ESL writing. Grabe and Kaplan (1996) felt that researcher write differently according to patterns within their culture. The research by Grabe and Kaplan (1996) on contrastive rhetoric revealed that the different cultural patterns affect the way the writer writes. This may sometimes affect the intended meaning or the way the content is portrayed.

Consequently, from this cognitive aspect of writing, the writer is seen as actively engaging in a thinking process while he or she writes. The research in this area revealed that there are differences in the way good and weak, expert and novice, as well as skilled and less skilled researcher write. Some researchers believe that these different researcher go through the same process but perform these processes differently, while others believe that they go through totally different processes. These different perspectives of writing have caused the teaching of writing to change over the years.

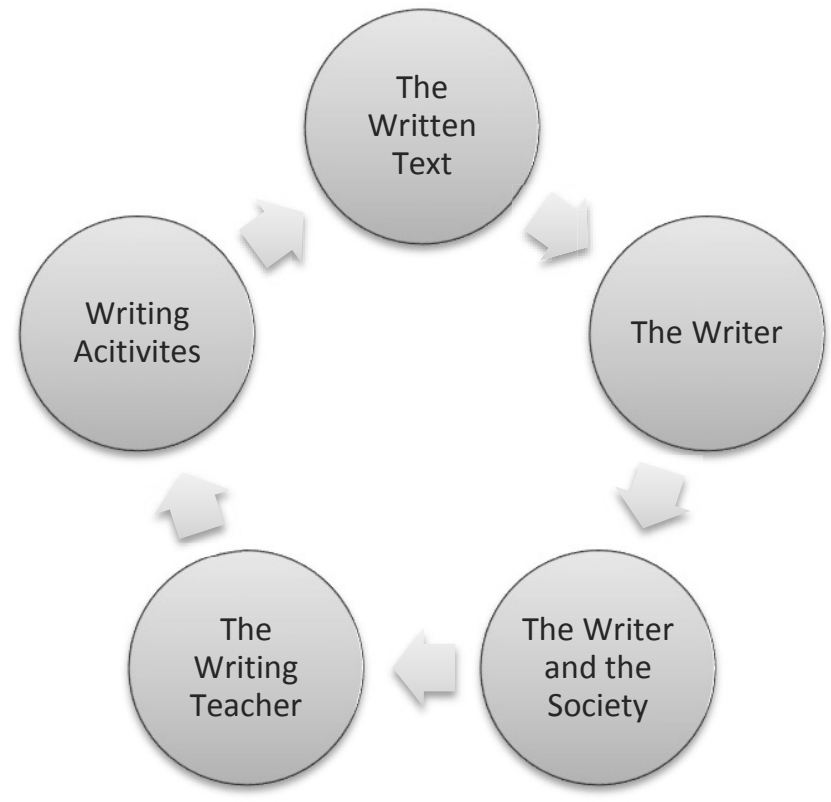

Figure 1. Development of the Teaching of Writing (Rahmat, 2011) 
Figure 1 above shows the development of teaching writing over the years. Back in the 1960 's, researchers in the teaching of writing gave their focus on creative writing. Later, in the 1970's, researchers began looking at what researcher actually did when they wrote and this marked the beginning of the cognitive orientation stage. The next stage began in 1980's and it was known as the Orientation Stage. This was the stage where researcher began to consider the social context of their writing. Researcher at this stage emphasized on writing essays for a purpose.

The focus of research in the teaching of writing changed after the 1990's and 2000's. Perhaps this shift was instigated from the previous focus on the social context of writing. The focus of writing research and classroom teaching shifted to catering to the audience. Writing lessons were planned to focus on readers' expectation. Among some of the popular research areas during this time was corrective feedback-self feedback, peer feedback and also teacher feedback. To date, there have been many studies on the teaching of writing in the classroom. Many of these researches in the teaching of writing were based on the theory of principled eclecticism Larsen-Freeman (2000). Based on this theory, teachers were encouraged to consider the different trends and ideas that have occurred historically before choosing a method that would fit their classroom setting. Over the years the focus of the writing classroom has undergone a variety of changes. At one point in time, writing classroom focus on the teaching of writing was on (a) the written text, (b) the writer, (c) the writer and social context, (d) the writer and audience, (e) the writing teacher and (f) lately, the focus is on improving writing activities.

Writing is an on-going process by the writer. According to Rahmat (2011), during writing, the writer goes back and forth while writing, accepting, and deleting ideas as the process progresses. The more the writer writes, the more he/she encounters problems. The more problems he/she learns to solve, the better he/she would become to face future problems in writing.

Past studies have shown that there are differences between male and female researcher. According to Hashemnejad, Zoghi and Amini (2014), there is a significant positive relationship in selfefficacy and writing performance. Writing efficacy refers to the students' beliefs in theirability to perform written task. When researcher are positive about their writing abilities, they would perform better in writing tasks.

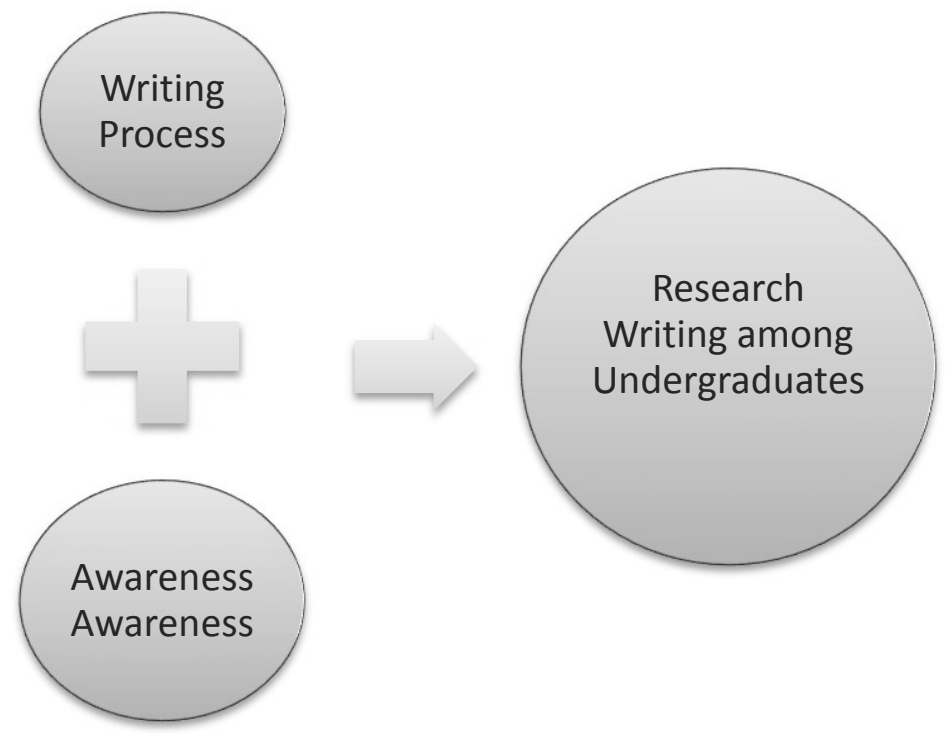

Figure 2. Theoretical Framework of the Study 
Figure 2 shows the theoretical framework of the study. This study looked at the undergraduates' perception on research writing with regards to writing process and audience analysis. Flower and Hayes (1981) believes that the writer used his/her own composing strategies when they are composing. This writing process involves the planning made by the writing before writing, translating ideas into words while writing, and later reviewing, evaluating and revising the essay before presentation to the audience. When researcher write with the audience in mind, the content and the structure of the essay will be different than when the essay was written form memory. The writer becomes conscious with what and how the content is displayed so that the audience would capture the same intended with the writer.

A study by Chiu (2008) was done to investigate gender differences in EFL college writing. The subjects of the study were 70 non-English major undergraduates (35 males and 35 females) from a national university in southern Taiwan. The subjects had to write four English paragraph-writing tests, including one pre- writing test, tow writing tests, and one post-writing test. They wrote four genres (cause-effect in the prewriting test, comparison paragraph and descriptive paragraphs and narrative in the post-writing test. The essays were scored based on five analytic criteria (content, organization, grammar, diction, and mechanics). Results reveal that female researcher wrote more (quantity) and had better scores (quality).

Another study by Carvalho (2002) reports a procedural facilitation strategy (method of applying an advanced strategy in a simplified way) to help learners self regulate their writing and revision and to develop greater audience awareness. Students were asked to evaluate and modify the text that they were writing. The writing was compared to a control group who did not receive any procedural facilitation. Both groups were given pre and post-test activities. The results indicated that the students' with higher degree of audience awareness scored better. It was also reported that the better researcher were less concerned with content generation and excessive checking of sentence structure.

The objective of this research is to explore the teaching of academic writing through audience awareness. Throughout the semester, the undergraduates were taught the writing process and giving attention to their audience. Specifically, this study focused on how audience awareness influenced their research writing.This research is done to answer: the questions: (a) are there significant differences between gender and writing process and audience awareness?; (b) in what ways does the writing process influence learners' research writing?; (c) in what ways does audience awareness influence the learners' research writing?

\section{METHODS}

This is a mixed qualitative and quantitative research. Data will be collected from journals of undergraduates in a research course. Their responses to a questionnaire will also be analysed quantitatively.

The target population for this study is students who signed for ESL academic writing course. The target population is undergraduates learning Research Methodology. This target population of undergraduates in their second last semester was chosen as purposive sampling they have undergone a few semesters of academic writing courses and had had writing experience.

The instrument chosen was a questionnaire. The questionnaire has three main sections. The first section is the demographic profile. Section B looks at the learners perception on their writing process. Section C looks at their perception on audience awareness and section D looks at their perception on research writing.

The data will be analysed using SPSS version 16. To determine if there is a significant association in the mean scores between gender and writing process, audience awareness, and research writing, correlation coefficient was conducted. 
Individual frequencies will also be tabulated in terms of bar charts.

FINDINGS AND DISCUSSION
The discussion of the findings will be done based on the three research questions.

Research question 1:

(a) Are there significant differences between gender and writing process and audience awareness?

Table 1: Correlations between Gender and Writing Process

\begin{tabular}{llrr}
\hline & & Gender & \multicolumn{1}{c}{$\begin{array}{l}\text { Writing } \\
\text { Process }\end{array}$} \\
\hline \multirow{2}{*}{ Gender } & Pearson Correlation & 1 & -.209 \\
\cline { 2 - 4 } & Sig. (2-tailed) & 51 & .142 \\
\cline { 2 - 4 } Writing Process & Pearson Correlation & -.209 & 51 \\
\cline { 2 - 4 } & Sig. (2-tailed) & .142 & 1 \\
\cline { 2 - 4 } & $\mathrm{N}$ & 51 & 51
\end{tabular}

To determine if there is a significant association in the mean scores between gender and writing process, correlation coefficient was conducted. Table 3 shows that there is a weak negative significant association between gender and writing process $(\mathrm{r}=-.209)$ and $(\mathrm{p}=.142)$.

Table 2: Correlations between Gender and Audience Awareness

\begin{tabular}{llrr}
\hline & & & \\
\hline \multirow{3}{*}{ Gender } & Gender & \multicolumn{1}{c}{$\begin{array}{c}\text { Audience } \\
\text { Awareness }\end{array}$} \\
\cline { 2 - 4 } & Pearson Correlation & 1 & $-.291^{*}$ \\
\cline { 2 - 4 } Audience Awareness (2-tailed) & 51 & .038 \\
\cline { 2 - 4 } & $\mathrm{N}$ & $-.291^{*}$ & 51 \\
\cline { 2 - 4 } & Pearson Correlation & .038 & 1 \\
\cline { 2 - 4 } & Sig. (2-tailed) & 51 & 51 \\
\cline { 2 - 4 } & $\mathrm{N}$ & &
\end{tabular}

*. Correlation is significant at the 0.05 level (2-tailed).

To determine if there is a significant association in the mean scores between gender and audience awareness, correlation coefficient was conducted. Figure 0.0 shows that there is a weak negative relationship between gender and audience awareness $(\mathrm{r}=-.291)$ and $(\mathrm{p}=.038)$. The correlation coefficient is significant at the 0.05 level.

Research question 2 :

(b) In what ways doe the writing process influence learners' research writing? 


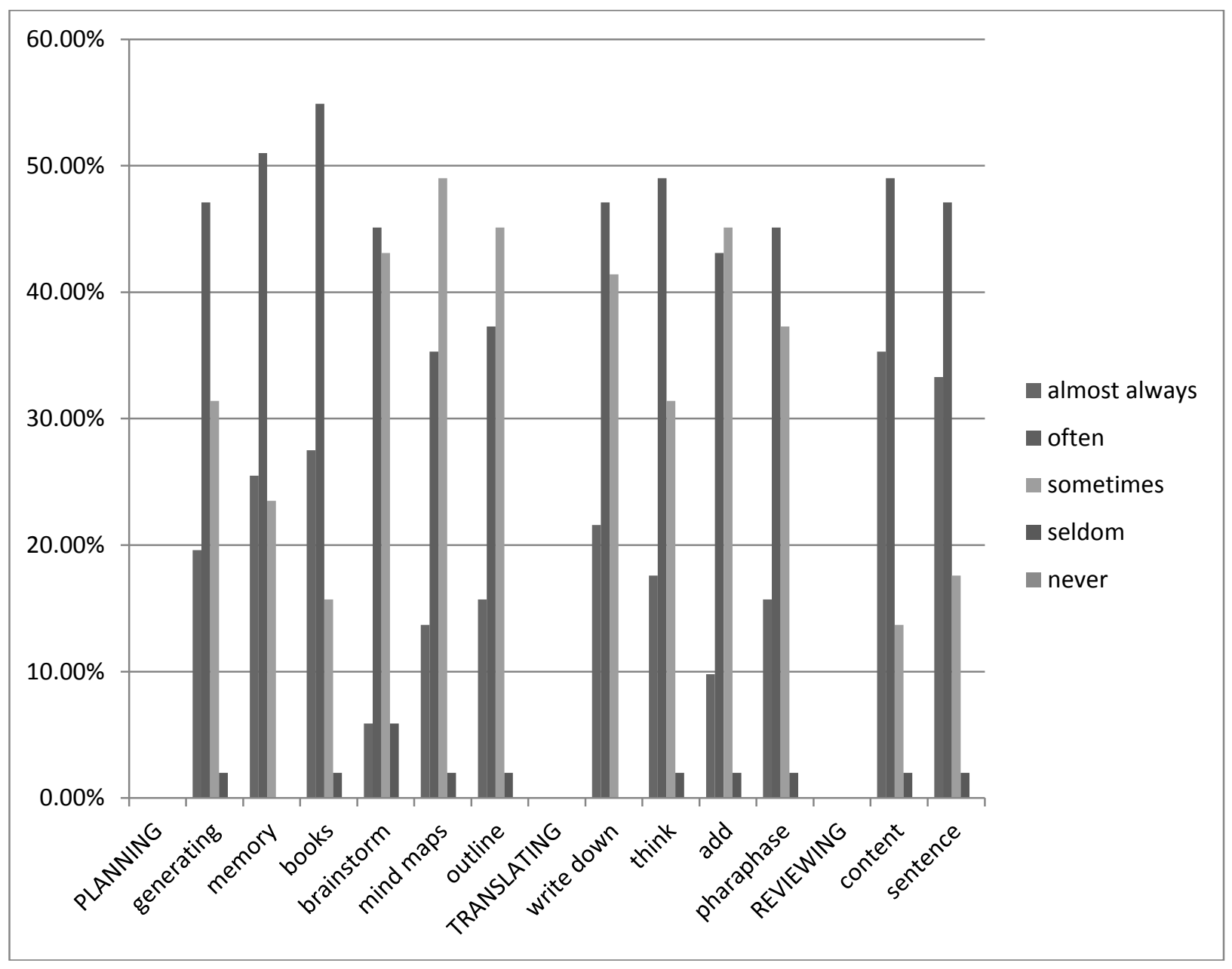

Figure 3. Bar chart showing the percentage of frequency for Writing process

The percentage for frequency for writing process is shown in figure 3 above. The learners were almost always reported to review their sentence structure $(35.5 \%)$ and content $(33.3 \%)$. This finding is in accordance with the research by Carvalho (2002) who also reported better researcher were less concerned with content generation. They also often planned their work by generating $(66.7 \%)$ ideas. Careful planning before writing is a characteristic of experienced researcher and the subjects in this study are experienced researcher too having been in their final semester. This finding is also in accordance with the study by Kara (2013) who also revealed that less experienced researcher lack planning skills when they wrote.

(c) In what ways do audience awareness influence the learners' research writing? 


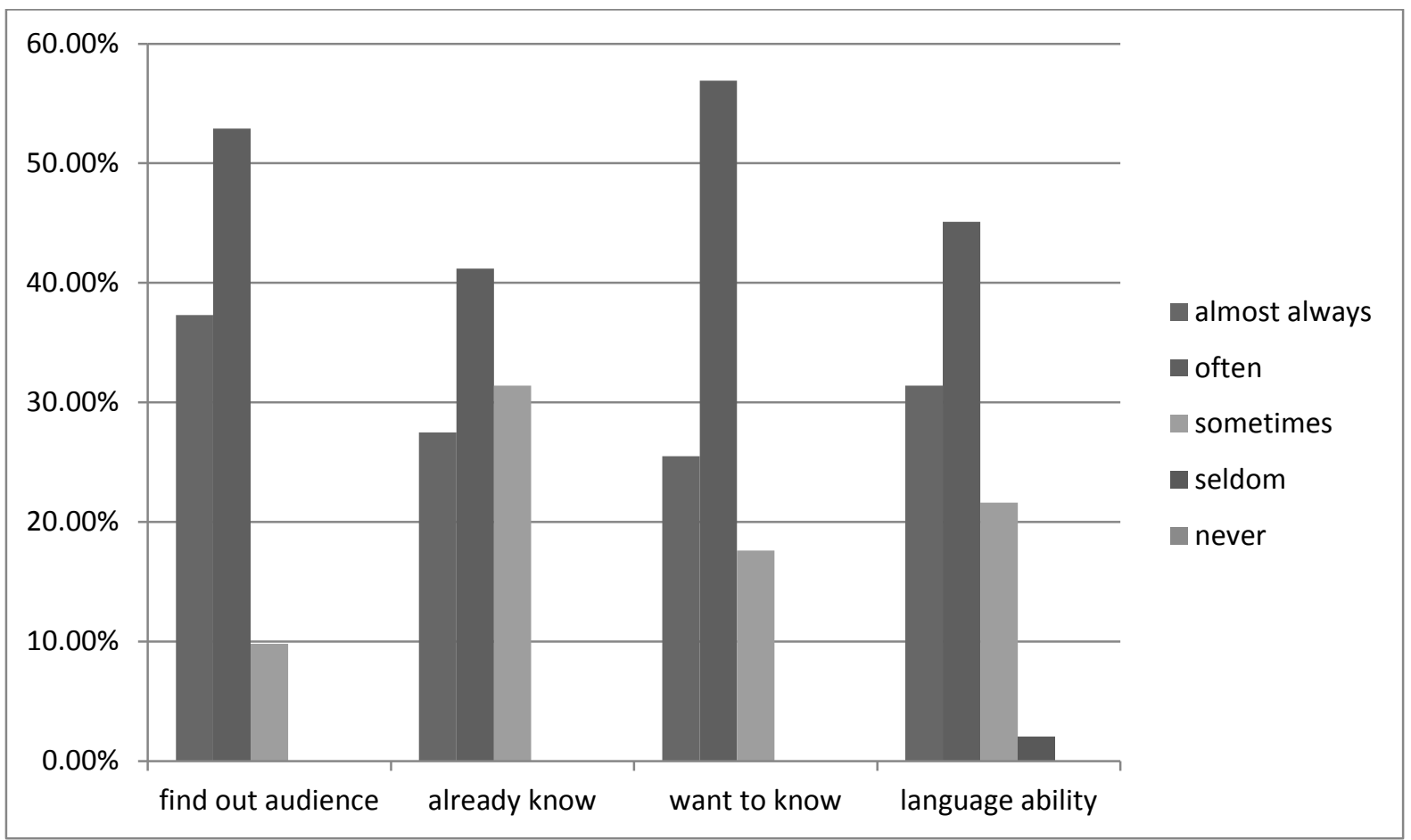

Figure 4. Percentage of Frequency for Audience Awareness

According to figure 4, the learners reported that they often found out the audience $(52.9 \%)$, found out what the audience wanted to know $(56.9 \%)$ and also the language ability of the audience (45.1\%). This finding is also in accordance with the study by Hanizah and Moore (2003) who found that being aware of the audience is a characteristic of experienced researcher.

\section{CONCLUSION}

This study was done on a group of undergraduates who were taught to focus on audience in their academic writing. In summary, students became more aware of the different stages of the writing process and they are planning, translating and reviewing. They learnt to give more emphasis on the planning instead on being overly concerned with the content and sentence structure. This is not to say that content generation and sentencing skills are not important in academic writing, but more time should be spent on the planning of the writing to enable the actual write-up process be made manageable. What differentiates between an experienced writer and a nonexperienced one is the time they spent to plan. This is reported by Noor HanimRahmat (2008) who also reported that experienced researcher took a longer time to begin writing and thus had more planning time than less experienced counterparts. In addition to that, being aware of the audience would include finding out who would be reading the finished product, finding out what the audience already knew, finding out what the audience wanted to know and finally, knowing the language capacity for the intended audience of the essay. The results of this study will have interesting implication towards undergraduates perception of research writing and how teachers can improve teaching approaches in research writing classrooms in future. The results of this research is only applicable to TESL undergraduates studying in an adult distance learning programmes. These undergraduates are full time primary school teachers teaching and studying full time in a university. 


\section{REFERENCES}

Carvalho,J. (2002). Developing Audience Awareness in Writing. Journal of Research in Reading, 25.271-282 Retrieved from http://www.ohioliteracyalliance.org /research/pdf/Carvalho.pdf

Chiu, C. (2008) An Investigation of Gender Differences in EFL College Writing. Proceedings of the BAAL Annual Conference 2008. Retrieved from http://www.baal.org.uk/proc08/chi u.pdf

Flower,L. \& Hayes, J. (1981) A Cognitive process Theory of Writing. College Composition and Commnunication. Vol 32, p265-387

Grabe,W. \& Kaplan, R.B. (1996). Theory and Practice of Writing-an applied Linguistic. UK: Routledge

Hanizah,Z.\&Moore,R.A. (2003). Audience Awareness in L1 and L2 Composing of Bilingual Researcher.Vol 7 (1) Retrieved from http://teslej.org/ej25/toc.html

Hashemnejad, F. Zoghi,M. \&Amini, D. (2014). The Relationship between SelfEfficacy and Writing Performance across Genders. Theory and Practice in Language Studies.Vol 4 (5) pp 1045-1052.

ISSN 1799-2591
Larsen-Freeman,D. (2000) Techniques and Principles in Language Teaching $\left(2^{\text {nd }}\right.$ Ed). Oxford: Oxford University Press

Rahmat, N.H. (2011) Approaches in the Teaching of ESL Writing. Selangor. Malaysia: UiTM Press.

(2008). Peer Review in the Writing Classroom: A Case Study of Written and Oral Stances on Revision Behaviour among ESL Researcher. Doctoral Thesis.

\section{ACKNOWLEDGMENTS}

I would like to thank my third year students of distant learning studying Bachelor of Education (TESL) for being a part of this research. I would also like to thank my university, Universiti Teknologi Mara for allowing me the opportunity to conduct this research. 